In the case of petroleum, formed from the same raw material, in itself extremely variable, other subsequent variables enter; one is the extreme delicacy and susceptibility of both the forming and formed petroleum to ever-continuous changes of temperature and pressure within the earth's crust; and the other is that petroleum can in general definitely be proved to have migrated at least several thousand feet, and during this process it may undergo chemical alteration, especially during contact with catalysers. In forming oil in the laboratory the principal variables at the disposal of the chemist are temperature, pressure, and catalysers; by varying these he obtains widely differing products from the same organic matter. In Nature, with infinite time added to the list of variables at present known, we seem to me to be not only fully justified but utterly unable to avoid expecting an almost infinite variety of petroleums.

I believe it has now been recognised that cholesterol and phytosterol are not necessarily any criterion as to animal or vegetable origin, since both can be made from a number of raw materials.

It is difficult to limit remarks on a subject so wide and important, but in conclusion I should like to make one further comment. Petroleum in the making at surface has been mentioned in various parts of the world, but these reports are frequently due to faulty observation or untenable hypotheses, and Djebel Zeit, Egypt, is no exception. I think all geologists are agreed that the oil there is, at latest, Miocene, and most probably of Cretaceous age, and that its presence in the corals is due to submarine and shore seepages, some of the oil from which lodged in the porous corals, and that on the local evidence it cannot possibly be explained by formation in situ.

Abbey Buildings, 8 Princes Street, G. W. HALSE.

Westminster, S.W.I, November 2.

The Ralline Genus Notornis, Owen.

THE ralline genus Notornis was established by Sir Richard Owen in I843 upon a series of bones sent him from New Zealand by the late Mr. Walter Mantell, in one of the earlier consignments of Moa bones discovered in the sand-dunes where the Maoris feasted. Owen designated his type species Notornis Mantelli. In the course of determining a collection of ornithological remains from turbaries, caves and kitchen middens from New Zealand and the Chatham Islands, containing many relics of those birds, I was bewildered, a few days ago, by discovering that this long-established genus had been boldly superseded by Messrs. Mathews and Iredale in their beautiful work on the "Birds of Australia," by the new generic designation, Mantellornis--one of the numerous topsyturvies their volumes contain.

In 1843 Notornis was supposed to be an entirely extinct rail. After the lapse of many decades, however, more than one specimen has been obtained in the flesh, an example of which, known to zoology for some thirty years as Notornis hochstetteri of Meyer, is now preserved in the Dresden Museum. This specimen was dissected by that distinguished biologist, the late Prof. Jeffery Parker, who found it, in its ostec logical details, so closely affine to $N$. Mantelli as to cause him (as he told me) much dorbt as to its differing in any character from Owen's species. The authors above cited have now renamed the Dresden specimen Mantellornis hochstetteri for the sole reason that Owen's genus was founded on fossil bonesafter all not really fossil. It must now be equally legitimate for the next daring Neozealandian systematist to follow this example and assign a new genus, say Iredalornis, to the Apteryx bones occurring in New Zealand pleistocene and more recent deposits, and in caves and cooking-ovens, the minutest anatomical details of whichagree with those of the Kiwis living within sight of the scenes in which their very own parents perished-a violent breach of the Rules of Nomenclature not less unscientific than the substitution of Mantellornis for Notornis.

It seems to be coming to this, if we are to be guided by these extremist authorities on nomenclature, that the very same creature is to be assigned to one genus when it is studied from the inside, and to another when (found alive) it is studied from the outside. Against such absurd genus-making-than which no more glaring example has surely been perpetrated in any reputable zoological publication$\mathrm{I}$, for one, desire to enter my strongest protest, in the interests of biological science, and against the confusion that must inevitably result if such procedure, as is described in this letter, is to be followed.

Redcliffe, Beaconsfield, Bucks, HENRY O. FORBES. October 28.

\section{Dr. Jesse W. Lazear and Yellow Fever.}

THE story of the death of Lazear as commonly told is that mentioned in NATURE of October 27, p. 631 , namely, that he " allowed himself to be bitten by mosquitoes that had fed on the blood of yellow fever patients." It may, however, be worth while to state that the mosquito-bite which killed him was inflicted, not experimentally, but by a "wild mosquito" in the ward in which he was working (September r9oo). This was told to me in Panama in I904 by Dr. T. C. Lyster, who was actually with Lazear when the insect bit him on the hand; and Lazear then remarked, "I wonder whether this creature is infected "-or words to that effect. It was Dr. J. Carroll, who had been previously, and experimentally, infected by mosquitoes fed on yellow-fever patients; but he recovered. Nevertheless, Lazear's case was almost as good as an experimental one. The whole heroic story will be found set forth in Dr. Howard A. Kelly's “ Walter Reed and Yellow Fever" (The Norman, Remington Company, Baltimore), and is given briefly in my Memoirs, p. 425 .

RONALD Ross.

\section{Life History of the Ephemeridæ.}

I HAVE been asked by a French observer, M. A. Gros of Marigny (Jura), France, if I can put him into touch with entomologists interested in the Ephemeridæ. M. Gros is the author of an illustrated brochure, "Études sur les premiers études des ephemeres du Jura français," which deals mainly with Ecdyonurus forcipula of Central Europe-not, I believe, found in the rivers of the British Isles. M. Gros would prefer to correspond in French if possible. He appears to have established some interesting facts, which may help us in our endeavours to transplant water-flies from one river to another. So many causes are denuding our rivers of their natural supplies of Ephemeridæ, etc., that it is most important to introduce fly from other waters if possible. It has been done, at least temporarily, in a few instances.

R. B: MARSTON,

I9 Adam Street, Strand, Editor, Fishing Gazette.

London, W.C.2, October 29. 